$\mathrm{A} \int_{\text {ass }} \mathrm{H}$

Received : 19.11.2015

Revised : 04.04.2016

Accepted : 18.04.2016

Members of the Research Forum

Associated Authors:

${ }^{1}$ Department of Agricultural

Economics, Dr. B.S. Konkan Krishi

Vidyapeeth, Dapoli, RATNAGIRI

(M.S.) INDIA
Author for correspondence :

J.M. TALATHI

Department of Agricultural

Economics, Dr. B.S. Konkan Krishi

Vidyapeeth, Dapoli, RATNAGIRI

(M.S.) INDIA

Email : hodecon@rediffmail.com
THEASIAN JOURNALOF HORTICULTURE

Volume 11 | Issue 1 | June, 2016 | 14-18

Visit us -www.researchjournal.co.in
RESEARCH PAPER

DOI : 10.15740/HAS/TAJH/11.1/14-18

\title{
Cost return and profitability of okra in Thane district of Maharashtra
}

\section{R.B. GODAMBE ${ }^{1}$, S.R. TORANE ${ }^{1}$, J.M. TALATHI AND P.J. KSHIRSAGAR ${ }^{1}$}

ABSTRACT : The study was undertaken to know cost returns and profitability for the farmer who want to diversify from traditional crops grown in the area. The per hectare input use in okra cultivation was 304.58 man days human labour, $10.34 \mathrm{~kg}$. seed, 3.68 tonn manures, $1654.48 \mathrm{~kg}$. fertilizers and 26.08 lit. plant protection Okra found to be highly labour intensive crop and provided proportionately higher employment of 304 days to family members i.e. for male and female members. Per hectare overall total cost of cultivation of okra i.e. cost C was Rs. 199264 in which contribution of cost A and cost B were Rs. 78681 (39.49\%) and Rs. 163095 (81.84\%), respectively. It was observed from the table that, the per hectare total cost of cultivation at overall level was Rs. 199264 and per quintal cost was 1070 resulting in to a yield of okra to the tune of 186.22 quintals. Per hectare profitability of okra cultivation was worked out by deducting different cost viz., Cost 'A', Cost ' $\mathrm{B}$ ' and Cost ' $\mathrm{C}$ ' from the per hectare gross returns. The overall profit at Cost A, Cost B and Cost C was Rs. 409956, Rs. 333149 and Rs. 296977, respectively. The per quintal cost (Cost 'C') of okra cultivation was Rs. 1011, Rs. 1067 and Rs. 1131, respectively, with an overall average being Rs. 1070.

KEY WORDS : Input use, Cost, Returns, Profitability

HOW TO CITE THIS ARTICLE : Godambe, R.B., Torane, S.R., Talathi, J.M. and Kshirsagar, P.J. (2016). Cost return and profitability of okra in Thane district of Maharashtra. Asian J. Hort., 11(1) : 1418, DOI : 10.15740/HAS/TAJH/11.1/14-18. 